UDC:

Short communication

\title{
Brine shrimp cytotoxic activity of methanolic extracts of Juniperus communis L. berries
}

\author{
Blagica Jovanova $^{1 *}$, Tatjana Kadifkova Panovska ${ }^{1}$, Svetlana Kulevanova ${ }^{2}$ \\ ${ }^{1}$ Institute of Applied Biochemistry, Department of Toxicology, Faculty of Pharmacy, \\ Ss. Cyril and Methodius University, Majka Tereza 47, 1000 Skopje, Republic of Macedonia \\ ${ }^{2}$ Institute of Pharmacognosy, Department of Pharmacognosy, Faculty of Pharmacy, \\ Ss. Cyril and Methodius University, Majka Tereza 47, 1000 Skopje, Republic of Macedonia
}

Received: October 2015; Accepted: November 2015

\begin{abstract}
Methanolic extracts from Juniperus communis L. berries collected from five different localities in the Republic of Macedonia were evaluated for their cytotoxicity by Brine shrimp lethality assay. The obtained cytotoxic activity is descending as follows: Pelister (128 $\mu \mathrm{g} /$ $\mathrm{mL})>$ Jakupica $(221 \mu \mathrm{g} / \mathrm{mL})>$ Prilep $(662 \mu \mathrm{g} / \mathrm{mL})>$ Demir Hisar $(863 \mu \mathrm{g} / \mathrm{mL})>$ Makedonski Brod $(969 \mu \mathrm{g} / \mathrm{mL})$. Berries collected from mountain areas (Pelister and Jakupica) demonstrated prominent cytotoxic effects, while berries collected from localities near urban areas exhibited lower cytotoxicity. Variations in their bioactivity are probably due to their complex phytochemical composition, which may vary with different ecological and geographical conditions.
\end{abstract}

Keywords: Juniperus communis L. berries, methanolic extracts, brine shrimp lethality assay, probit analysis, $\mathrm{LC}_{50}$

\section{Introduction}

Juniperus communis L. (common juniper) is an evergreen shrub belonging to the family Cupresaceae and is widely distributed throughout the Northern Hemisphere, from cool temperate to polar regions. Juniper trees are adapted for optimal growth on a wide range of soils and soil $\mathrm{pH}$, and are drought tolerant (Lim, 2012). Common juniper shrubs grow natively in all parts of the Republic of Macedonia (Micevski, 1998). Ripe berries and needles have long been used for the treatment of gastrointestinal conditions, dyspepsia, flatulence, egzema (Charles, 2013). Indigenous people from the East were using the juniper berries as herbal tea to treat urinary tract infections and as tonic against flu, muscle aches and kidney problems, while the needles were mainly used as remedy for acute and chronic cystitis, albuminuria, renal suppression,

\footnotetext{
*blagicajovanova13@gmail.com
}

amennorhoea (Bais et al., 2014). Despite the wide usage in traditional medicine, the biological activity of the Juniperus communis berries still remains insufficiently examined. Previous studies on the biological activity of the berries demonstrated their antibacterial, fungicidal (Pepeljnjak et al., 2005), antioxidant (Höferl et al., 2014), anticholinesterase (Orhan et al., 2011) and antiinflamatory (Han and Parker, 2017) activity. However, limited data are reported on their cytotoxic properties. Therefore, the aim of this study was in vivo determination of the cytotoxic potential of Juniperus communis L. berries collected from several localities of the Republic of Macedonia.

\section{Materials and methods}

Plant materials

The plant material was harvested in the year 2010 and 2011 from five different localities: Pelister (JCP), Jakupica 
(JCJ), Prilep (JCPr), Demir Hisar (JCH) and Makedonski Brod (JCB). Dried plant material was milled to fine powder and stored in airtight containers until use.

\section{Preparation of extracts}

Plant samples were extracted with methanol in ultrasonic bath. Obtained filtrates were evaporated until dry and later freeze dried and preserved at $-18{ }^{\circ} \mathrm{C}$ in a dark place until use. Lyophilizates were reconstituted with DMSO (dimethyl sulfoxide).

\section{Brine shrimp lethality assay}

The cytotoxic potential of the extracts was evaluated by Brine Shrimp Lethality Assay in vivo (Meyer et al., 1982) based on the number of dead Artemia salina nauplii after 24 hours exposure to the plant samples. $\mathrm{K}_{2} \mathrm{Cr}_{2} \mathrm{O}_{7}$ (potassium dichromate) was used as a positive control in a concentration range from 0.01 to $10 \mathrm{mg} / \mathrm{mL}$. Final results were expressed as $\mathrm{LC}_{50}$ values using probit regression analysis (Finney, 1952). LC $_{50}$ values represent the concentration of each extract needed to elicit mortality in $50 \%$ of the tested population of brine shrimps.

\section{Toxicity criteria and classification of extracts}

Based on the obtained $\mathrm{LC}_{50}$ values, plant extracts were classified according two scales of toxicity: Meyer's scale and Clarkson's scale (Meyer et al., 1982; Clarkson et al., 2004). Both scales classify extracts as toxic if their $\mathrm{LC}_{50}$ values were below $1000 \mu \mathrm{g} / \mathrm{mL}$, while Clarkson's scale additionally categorizes them as extracts with high $(0-$ $100 \mu \mathrm{g} / \mathrm{mL})$, moderate $(100-500 \mu \mathrm{g} / \mathrm{mL})$ and low $(500-$ $1000 \mu \mathrm{g} / \mathrm{mL})$ toxicity.

\section{Results and discussion}

According the obtained data, it was established that all tested samples possess cytotoxic potential in different extent (Table 1). Their cytotoxic bioactivities diminish in the following order: JCP $(128 \mu \mathrm{g} / \mathrm{mL})>\mathrm{JCJ}(221 \mu \mathrm{g} / \mathrm{mL})$ $>\operatorname{JCPr}(662 \mu \mathrm{g} / \mathrm{mL})>\mathrm{JCH}(863 \mu \mathrm{g} / \mathrm{mL})>\mathrm{JCB}(969 \mu \mathrm{g} /$ $\mathrm{mL})$. Most prominent cytotoxic effect was observed for the berries collected from Pelister $(128 \mu \mathrm{g} / \mathrm{mL})$ and the lowest cytotoxic activity was demonstrated by the berries collected from Makedonski Brod $(969 \mu \mathrm{g} / \mathrm{mL})$.

The trend of mortality rate for the Artemia nauplii after their 24-hour exposure to each sample and to the positive control are demonstrated on Figure 1. A notable increase in toxicity was observed for the samples collected from Pelister $(40 \%$ to $100 \%)$ and Jakupica (50\% to $100 \%)$ at concentrations $1 \mathrm{mg} / \mathrm{mL}$ and $3 \mathrm{mg} / \mathrm{mL}$, and for the positive control $\mathrm{K}_{2} \mathrm{Cr}_{2} \mathrm{O}_{7}(100 \%$ mortality rate at $1 \mathrm{mg} / \mathrm{mL})$. Moreover, a maximal mortality rate of $100 \%$ at the highest concentration $(10 \mathrm{mg} / \mathrm{mL})$ was observed for all samples except for the berries collected from Makedonski Brod.

$J$. communis berries collected from the localities of Pelister and Jakupica were classified as moderately toxic, while samples collected from locations near the cities of Prilep, Demir Hisar and Makedonski Brod were classified as extracts with low toxicity. The amount of certain bioactive compounds present in the berries may significantly vary as a result of differences in temperature, soil chemistry, soil acidity (Ložiené and Labokas, 2012), light quality (Artemkina et al., 2016), rainfall levels, season (Peñuelas et al., 2002) and altitude of the habitat (Martz et al., 2009). Ecological conditions of plant growth may significantly change the phytochemical composition of the plants upon transition from the base to the top of the mountains (Artemkina et al., 2016). In the current research, a moderate cytotoxicity was obtained for the samples collected from mountain areas (Pelister and Jakupica), while the berries collected from the localities near urban area with an altitude range from $550 \mathrm{~m}$ to $650 \mathrm{~m}$ (Prilep, Demir Hisar and Makedonski Brod) demonstrated low cytotoxicity. The variations in their cytotoxic activity are probably related to their complex phytochemical composition. This observation is supported by previous research on the variability in concentration of bioactive compounds present in Juniperus berries as a result of different latitude and altitude of the

Table 1. Cytotoxic potential of methanolic extracts of Juniperus communis berries collected from 5 different localities and a positive control according the Brine Shrimp Lethality Assay

\begin{tabular}{lccccc}
\hline \hline Location & Abbr. & Year & $\mathrm{LC}_{50}(\mu \mathrm{g} / \mathrm{mL})$ & Meyer's scale & Clarkson's scale \\
\hline Pelister & JCP & 2010 & 128 & toxic & moderately toxic \\
Jakupica & JCJ & 2010 & 221 & toxic & moderately toxic \\
Prilep & $\mathrm{JCPr}$ & 2011 & 662 & toxic & low toxic \\
Demir Hisar & $\mathrm{JCH}$ & 2011 & 863 & toxic & low toxic \\
Makedonski Brod & $\mathrm{JCB}$ & 2010 & 969 & toxic & low toxic \\
Positive control & & $\mathrm{LC}_{50}(\mu \mathrm{g} / \mathrm{mL})$ & toxic & highly toxic \\
$\mathrm{K}_{2} \mathrm{Cr}_{2} \mathrm{O}_{7}$ & & 41 & &
\end{tabular}



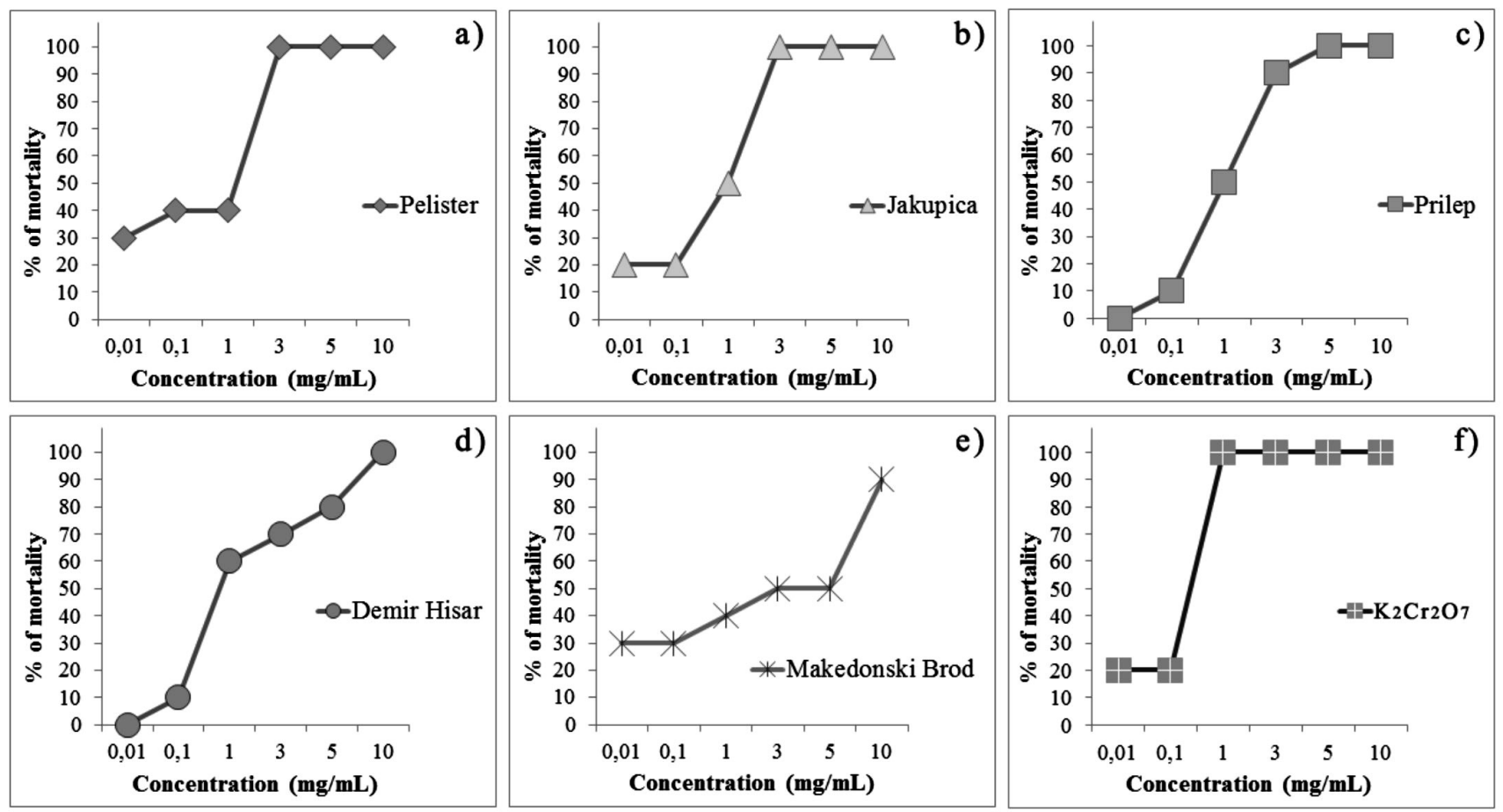

Fig. 1. Trend of mortality for A. salina against concentration for berries collected from a) Pelister; b) Jakupica; c) Prilep; d) Demir Hisar; e) Makedonski Brod; and the positive control f) Potassium dichromate.

habitat. The proportion of limonene, sabinene, 3 -carene, myrcene, $\beta$-pinene and terpinolene, the most abundant compounds in the juniper essential oil was significantly higher in species collected from higher altitudes compared to lower habitats, as it was demonstrated by Martz et al. (2009). The proportion of $\alpha$-pinene was affected insignificantly by the geographical factors (Ložienè and Labokas, 2012). Taking into account their complex phytochemical composition, it is highly probable that the bioactive profile of the examined species is due to the synergic action of several phytochemical components with cytotoxic potential.

Additionally, $\mathrm{LC}_{50}$ values obtained for the most potent samples in the current research were similar to obtained values for the cytotoxic potential against several in vitro cell lines demonstrated in previous studies on the bioactivity of Juniperus communis berries collected from different localities. In the study of Ghaly et al. (2016), treatment with methanolic extracts from the berries resulted in a significant cytotoxic activity against human breast cancer cells MCF7 and the human colon cancer cells HCT-116. The aquaeous extract of leaf and berries from Juniperus communis L. var. saxatilis Pall. demonstrated cytotoxic and antitumor activity against CRPC (Castration-resistant prostate cancer) cells in the study of Eryilmaz et al. (2017). The anticancer activity of Juniperus communis berries is also possible via induction of cell cycle arrest which has an important role in cancer prevention. This type of inhibitory activity was observed for isolated compounds from methanolic extract of $J$. communis berries against the cell cycle progression in p53-null human cancer $\mathrm{CaLu}-6$ cells in the study of Marino et al. (2011).

Furthermore, our results are in conjuction with previously reported studies on other species from the Juniperus genus. Methanolic extracts from Juniperus drupacea Labill. berries demonstrated significant cytotoxic potential against Artemia larvae $\left(\mathrm{LC}_{50} 489.47 \pm 27.8 \mu \mathrm{g} /\right.$ $\mathrm{mL}$ ) and a significant decrease in $\mathrm{HepG} 2$ cells viability $(5-10 \mu \mathrm{g} / \mathrm{mL}$ ) (Miceli et al., 2011). Moreover, similar results were also obtained for the hydroalcoholic extract of Juniperus sabina berries against HeLa and MDA-MB-468 cells in the study of Jafarian-Dehkordi et al. (2004).

\section{Conclusion}

Overall, Juniperus communis berries were identified as samples with a certain cytotoxic potential in vivo, and the obtained results suggest that the amount of bioactive compounds could be correlated with the altitude of their habitat. Berries collected from Pelister and Jakupica demonstrated moderate cytotoxicity, while the berries collected from localities near Prilep, Demir Hisar and Makedonski Brod were characterized with low cytotoxic 
activity. Obtained results in the current research emphasize the need of more intensive natural product screening for new bioactive compounds with cytotoxic properties. Therefore, further studies would be needed to clarify the mechanism of cytotoxicity and to identify the responsible bioactive compounds present in berries from Juniperus communis $\mathrm{L}$.

\section{References}

Artemkina, N.A., Orlova, M.A., Lukina N.V., 2016. Chemical composition of Juniperus sibirica needles (Cupressaceae) in the forest-tundra ecotone, the Khibiny Mountains. Rus. J. Ecol. 47(4), 321-328.

Bais, S., Singh Gill, N., Rana, N., Shandil, S., 2014. "A Phytopharmacological review on a medicinal plant: Juniperus communis," Int Schol Res Not. 2014, Article ID 634723, 6 pages, doi:10.1155/2014/634723.

Charles, D.J., 2013. Chapter 32: Juniper, In: Charles, D.J., Antioxidant properties of spices, herbs and other sources. $1^{\text {st }}$ Ed. Springer-Verlag New York, pp. 357-362.

Clarkson, C., Maharaj, V.J., Crouch, N.R., Grace, O.M., Pillay, P., Matsabisa, M. G., Bhagwandin, N., Smith, P.J., Folb, P.I., 2004. In vitro antiplasmodial activity of medicinal plants native to or naturalized in South Africa. J. Ethnopharm. 92, 177-191.

De Marino, S., Cattaneo, F., Festa, C., Zollo, F., Iaccio, A., Ammendola, R., Incollingo, F., Iorizzi, M., 2011. Imbricatolic acid from Juniperus communis L. prevents cell cycle progression in CaLu-6 cells. Planta Med. 77, 18221828.

Eryilmaz, I.E., Egeli, Ü., Çeçener, G., Tunca, B., Şahin, S., Malyer, H., 2017. In vitro cytotoxic and antitumoral effects of Juniperus communis leaf and berry extracts on Castrationresistant prostate cancer cells. Conference paper: 15th International Congress of Histochemistry and Cytochemistry. doi: 10.5505/2017ichc.PP-103.

Finney, D., 1952. Probit analysis: a statistical treatment of the sigmoid response curve. $2^{\text {nd }}$ Ed. Cambridge University Press, Cambridge.

Ghaly, N.S., Mina, S.A., Younis, N.A.H., 2016. In vitro cytotoxic activity and phytochemical analysis of the aerial parts of $\mathrm{J}$. communis L. cultivated in Egypt. J. Pharm. Sci. \& Res. 8(2), 128-131.

Han, X., Parker, T.L., 2017. Anti-inflammatory activity of Juniper (Juniperus communis) berry essential oil in human dermal fibroblasts. Cogent Medicine. 4, 1306200.
Höferl, M, Stoilova, I., Schmidt, E., Wanner, J., Jirovetz, L., Trifonova, D., Krastev, L., Krastanov, A., 2014. Chemical composition and antioxidant properties of juniper berry (juniperus communis 1.) Essential oil. Action of the essential oil on the antioxidant protection of saccharomyces cerevisiae model organism. Antioxidants 3, 81-98.

Jafarian-Dehkordi, A., Emami, S.A., Saeidi, M., Sadeghi, H., 2004. Cytotoxicologic studies of the extracts of Iranian Juniperus sabina and Platycladus orientalis on cancer cells. J. Res. Med. Sci. 5, 205-209.

Lim, T.K., 2012. Juniperus communis. In: Edible medicinal and non-medicinal plants Vol. 1 Fruits. Springer Science + Business Media B.V.

Ložienè, K., Labokas, J., 2012. Effects of abiotic environmental conditions on amount and enantiomeric composition of a-pinene in Juniperus communis L. Biochem. System Ecol. 44, 36-43.

Martz, F., Peltola, R., Fontanay, S., Duval, R.E., JulkunenTiitto, R., Stark, S., 2009. Effect of latitude and altitude on the terpenoid and soluble phenolic composition of juniper (Juniperus communis) needles and evaluation of their antibacterial activity in the boreal zone. J. Agric. Food Chem. 57, 9575-9584.

Meyer, B.N., Ferrigni, N.R., Putnam, J.E., Jacobsen, L.B., Nichols, D.E., McLaughlin, J.L., 1982. Brine Shrimp: A convenient general bioassay for active plant constituents. Planta Med. 45, 31-34.

Miceli, N., Trovato, A., Marino, A., Bellinghieri, V., Melchini, A., Dugo, P., Cacciola, F., Donato, P., L. Mondello, L., Güvenç, A., De Pasquale, R., Taviano, M.F., 2011. Food Chem Toxicol. 49, 2600-2608.

Micevski, K., 1998. Flora na R. Makedonija. 1st Ed. Skopje: Makedonska akademija na naukite i umetnostite.

Orhan, N., Orhan, I.E., Ergun, F., 2011. Insights into cholinesterase inhibitory and antioxidant activities of five Juniperus species. Food Chem Toxicol. 49, 2305-2312.

Peñuelas, J., Castells, E., Joffre, R., Tognetti, R., 2002. Carbonbased secondary and structural compounds in Mediterranean shrubs growing near a natural $\mathrm{CO}_{2}$ spring. Global Change Biol. 8, 281-288.

Pepeljnjak, S., Kosalec, I., Kalođera, Z., Blažević, N., 2005. Antimicrobial activity of juniper berry essential oil (Juniperus communis L., Cupressaceae). Acta Pharm. 55, $417-422$. 


\title{
Резиме
}

\section{Цитотоксична активност на метанолни екстракти од бобинки на Juniperus communis L. врз солени ракчиња (Artemia salina)}

\author{
Благица Јованова ${ }^{1 *}$, Татјана Кадифкова Панов̈ска ${ }^{1}$, Светлана Кулеванова ${ }^{2}$ \\ ${ }^{1}$ Инстиитууй за Применета биохемија, Кайеора за Токсиколоіија, \\ Фармацевитски факулиети, Универзитети, ,Св. Кирил и Метоояи”, Мајка Тереза 47, \\ 1000 Скойје, Рейублика Макеоонија

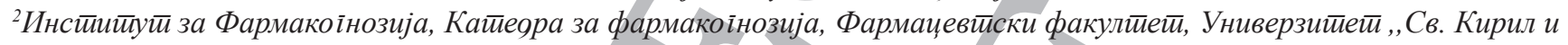 \\ Мешооииј”, Мајка Тереза 47, 1000 Скойје, \\ Рейублика Макеоонија
}

Клучни зборови: Juniperus communis L. бобинки, метанолни екстракти, тест со леталност на солени ракчиња, пробит анализа, $\mathrm{LC}_{50}$

Цитотоксичниот потенцијал на метанолни екстракти од Juniperus communis бобинки собрани од пет локалитети во Република Македонија е евалуиран со примена на Тестот со солени ракчиња. Добиените резултати за цитотоксичноста опаѓаат според следниот редослед: Пелистер $(128 \mu \mathrm{g} / \mathrm{mL})>$ Јакупица $(221 \mu \mathrm{g} / \mathrm{mL})>$ Прилеп $(662 \mu \mathrm{g} / \mathrm{mL})>$ Демир Хисар $(863 \mu \mathrm{g} / \mathrm{mL})>$ Македонски Брод $(969 \mu \mathrm{g} / \mathrm{mL})$. Бобинките собрани од планинскиот предел предизвикаа значајни цитотоксични ефекти кај ракчињата, додека бобинките собрани од локалитети блиску до урбани подрачја се карактеризираат со пониска цитотоксичност. Варијациите во нивната биоактивност најверојатно се должат на комплексниот фитохемиски состав, што може да варира при различни еколошки и географски услови. 
